\title{
Reproduction of white-tailed deer in a seasonally dry tropical forest of Costa Rica: a test of aseasonality
}

\author{
Todd K. Fuller, * Alexander M. Silva, Victor H. Montalvo, Carolina Sáenz-Bolaños, and \\ EDUARDo CARrillo J.
}

Department of Environmental Conservation, University of Massachusetts, Amherst, MA 01003, USA (TKF, AMS, VHM, CS-B) Instituto Internacional en Conservación y Manejo de Vida Silvestre, Universidad Nacional, Apdo. 1350-3000, Heredia, Costa Rica (VHM, CS-B, ECJ)

* Correspondent: tkfuller@eco.umass.edu

\begin{abstract}
The reproductive season of white-tailed deer (Odocoileus virginianus) has been hypothesized to be aseasonal south of about $14^{\circ}-18^{\circ} \mathrm{N}$ latitude, where annual variation in day length is low. We tested this idea by using camera-trap data (1,336 photographed individuals identified by age and sex) collected during 2011-2017 in the dry tropical forest of Santa Rosa National Park, northwest Costa Rica, where wet and dry seasons are welldefined. We identified variation in monthly occurrence of spotted deer fawns, as well as the status of antler growth of male deer, specifically related to the very seasonal environment of the region. Year-round reproduction likely occurs, but the rainfall pattern in the area greatly influences the relative frequency of reproductive indicators, with most births occurring during the dry season, and a second peak occurring toward the latter part of the wet season. We speculate that food resources are the major influence on reproductive patterns, and that variation in types and timing of food resource availability likely account for the variation in reproductive patterns.
\end{abstract}

Key words: fawns, Odocoileus virginianus, reproduction, seasonality, white-tailed deer

La temporada reproductiva del venado de cola blanca (Odocoileus virginianus) se ha hipotetizado como algo estacional al sur de aproximadamente $14^{\circ}-18^{\circ}$ de latitud norte, donde la variación anual en el largo del día es baja. Pusimos a prueba esta hipótesis usando datos de captura de cámara (1.336 individuos fotografiados identificados por edad y sexo) recolectados durante 2011-2017 en el bosque tropical seco del Parque Nacional Santa Rosa, en el noroeste de Costa Rica, donde las estaciones húmedas y secas están bien definidas. Encontramos variación en la incidencia mensual de cervatos manchados, así como el estado del crecimiento de las astas de machos de venado, específicamente relacionados con variaciones estacionales en el medioambiente de la región. Es probable que se de la reproducción durante todo el año, pero el patrón de precipitación en el área influye en gran medida en la frecuencia relativa de los indicadores reproductivos: la mayoría de los nacimientos se dan durante la estación seca, con un segundo pico hacia la última parte de la estación lluviosa. Especulamos que los recursos alimenticios son la principal influencia en patrones reproductivos, y que la variación en los tipos y el tiempo de disponibilidad de recursos alimenticios probablemente explica la variación en patrones reproductivos.

Key words: cervatillos, Odocoileus virginianus, reproducción, estacionalidad, venado cola blanca

Seasonal reproduction is typical for temperate herbivorous mammals such as cervids, and is particularly notable at higher latitudes where cold winters provide limited forage and spring warming brings flushes of proteinaceous vegetation (Lincoln 1992; Asher 2011). While seasonal changes in temperature, rainfall, and food availability are the environmental factors that influence the survival of young and adults, and thus are ultimately responsible for dictating the timing of the birth season (Lincoln and Short 1980; Verme and Ullrey 1984), it is generally accepted that entrainment of seasonal reproductive cycles is effected by endogenous recognition of photoperiod changes (Asher 2011).

(C) 2019 American Society of Mammalogists, www.mammalogy.org 
The timing of the breeding season and parturition for whitetailed deer (Odocoileus virginianus) is thus linked to photoperiod and, as such, there is a general continuum in breeding season timing associated with latitude (Ditchkoff 2011). Most of the geographic range of white-tailed deer is in temperate North America (Gallina and Lopez Arevalo 2016) where there is major change in the photoperiod over the year and where a long, cold winter period leads to highly concentrated reproductive season: breeding in November and December and fawning in June and July (Goss 1983:239, figure 134). In Florida, however, 1 - to 2-month-long breeding seasons in each of four study areas (latitude $26^{\circ} 30^{\prime}-30^{\circ} 30^{\prime} \mathrm{N}$ ) were as much as 6 months asynchronous (Richter and Labisky 1985). In the southernmost tropical range of white-tailed deer, from southern Mexico to northern South America, the reproductive season has been hypothesized (based on antler cycles keyed to solstice day lengths-Goss 1983) to be aseasonal south of about $14^{\circ}-18^{\circ}$ latitude (i.e., southern Honduras to southern Mexico). At these latitudes, annual day-length variation is low (i.e., difference in day length on 21 June versus 21 December $=1 \mathrm{~h} 40$ min versus $2 \mathrm{~h} 10 \mathrm{~min}$, in southern Honduras and southern Mexico, respectively; http://www.solartopo.com/daylength.htm).

Goss (1983:245) encouraged specific confirmation of this aseasonality hypothesis with more data on the life cycles of Latin American deer, but information related to this proposition for white-tailed deer (and other tropical cervids-Asher 2011) has been limited (but see Gallina et al. 2010) and somewhat contradictory. White-tailed deer in the Virgin Islands $\left(17^{\circ} \mathrm{N}\right)$ gave birth in every month, with a possible peak during NovemberJanuary, perhaps related to variation in rainfall (Webb and Nellis 1981). In Guatemala $\left(14^{\circ}-15^{\circ} \mathrm{N}\right)$, in late March, fawns $\sim 2$ weeks old were seen at the same time as 6-month-old fawns (Saunders et al. 1950:156) and a female with two small fawns was seen in May, suggesting asynchrony. In Honduras $\left(13^{\circ}\right.$ $\left.16^{\circ} \mathrm{N}\right), 14$ of 52 females were identified as giving birth from January through June and in September (Klein 1982).

In Venezuela $\left(7^{\circ}-8^{\circ} \mathrm{N}\right)$, six parturition dates of captive females occurred "year-round" (Stuwe 1985), and on the Venezuelan llanos $\left(\sim 1^{\circ}-7^{\circ} \mathrm{N}\right)$, fawning was said to be possible year-round, with most births during the July-November rainy season, with a second peak during February and March in the dry season (Brokx 1984). Based on admittedly small samples, Branan and Marchinton (1987) indicated that in Suriname $\left(3^{\circ}-6^{\circ} \mathrm{N}\right)$, fawns were born from at least September through February, but they could not rule out year-round fawning and speculated that fawn survival would be lowest during the dry season. In Colombia $\left(5^{\circ} \mathrm{N}\right)$, however, 16 birth dates occurred from September to March with a peak in December (i.e., most of the dry season); this seasonality was attributed to the adverse effects of prolonged heavy rains on fawn survival (Blouch 1987). These results suggest that, in the tropics, reproductive patterns of white-tailed deer, without a major influence of photoperiod, may sometimes reflect rainfall patterns that influence seasonal availability of food, predation pressure, or survival (Asher 2011), similar to what was proposed to explain the variation in Florida (Richter and Labisky 1985), and thus show seasonality.
In Costa Rica, white-tailed deer occur mostly in deciduous forest and other relatively open habitats from sea level to perhaps 1,580 m (Wainwright 2007; E. Carrillo J. and C. Sáenz-Bolaños, pers. obs.), and throughout this range annual precipitation patterns vary regionally (Waylen et al. 1996). Along the Caribbean coast, monthly precipitation is fairly consistent among months, but with noticeable decreases in October and March. In northern Costa Rica, and southwest along the Pacific Ocean, most rain falls from April to December, with some rain in January-March, as well. In the northwest Pacific coast, however, the rainy season is from May to mid-December with nearly no rainfall in the dry season between January and April, and knowledge of reproduction by white-tailed deer in Costa Rica is based mostly on observations made in this northwestern dry seasonal forest of the Guanacaste region. In this area, Janzen (1983) noted seeing small spotted small fawns in February and larger ones in May-July. On nearby San Lucas Island in the Golf of Nicoya, births occurred during JanuaryMay (though $94 \%$ of 64 observations were in February and March), adult male deer with antlers in velvet were observed in March through July, and males with hard antlers were seen mostly during August-January (Rodríguez and Solís 1987, 1994). As a result, the birth season of white-tailed deer in this portion of Costa Rica currently is considered to be mostly in February and March in the dry season (Wainwright 2007).

In light of the observations available so far, and to better test the Goss (1983) hypothesis of aseasonal reproduction of deer occurring south of Honduras, we utilized camera trap data collected during 2011-2017 in the dry tropical forest of northwest Costa Rica. We sought to identify the variation in monthly occurrence of spotted deer fawns, as well as the status of antler growth of male deer, specifically as related to the very seasonal environment of the region. We predicted that we would identify year-round reproduction, but that the rainfall pattern in the area would influence the relative frequency of reproductive indicators, and thus show seasonal influences. We also checked to see if there was any seasonality to the proportion of twins born that might be related to relative nutritional status of adult females.

\section{Materials and Methods}

Study site-We collected deer photos in Santa Rosa National Park (SRNP), one of the four national parks within the Guanacaste Conservation Area (GCA) in northwest Costa Rica (Boza 1992). At SRNP headquarters (latitude $10^{\circ} 50^{\prime} \mathrm{N}$ ), day length on 21 June is just $1 \mathrm{~h}$ and 16 min longer than on 21 December. The $387-\mathrm{km}^{2}$ SRNP is dominated by one of the few seasonally dry forests remaining in Central America (Jimenez et al. 2016). The park contains evergreen forests dominated by live oak (Quercus oleoides) but also including a large number of other species that co-occur in the adjacent mixed deciduous forest where oaks are rare, and more typical species from tropical dry forest (Powers et al. 2009). The forests on the hill slopes and in the lowlands are more diverse and with varying degrees of deciduousness (e.g., 20\% evergreen hillsides to $>95 \%$ evergreen lowlands). Several areas of Santa Rosa are covered with a mosaic of pasture and secondary growth in various stages of 
regeneration with areas that have different land-use histories, past land-use intensities, as well as different occurrences of discrete anthropogenic events such as fire (Kalacska et al. 2004).

Mean annual rainfall in SRNP totals $\sim 1,600 \mathrm{~mm}$ but is highly seasonal; the wet season (months with an average $\geq 100 \mathrm{~mm}$ of rain; average maximum temperatures $\sim 29-31^{\circ} \mathrm{C}$ ) is May to November, and the dry season (with almost no rain and maximum temperatures $>35^{\circ} \mathrm{C}$ ) is December to April (Fig. 1A; cf. Janzen 1993). During 2011-2017, total precipitation during the rainy season varied from 617 to $2,531 \mathrm{~mm}$ (mean $=1,524$, $C V=0.41$ ), and monthly averages had a coefficient of variation of 0.64 (Supplementary Data SD1).

During the dry season, many forest patches lose their leaves and few evergreen-forest patches retain them. In addition, most
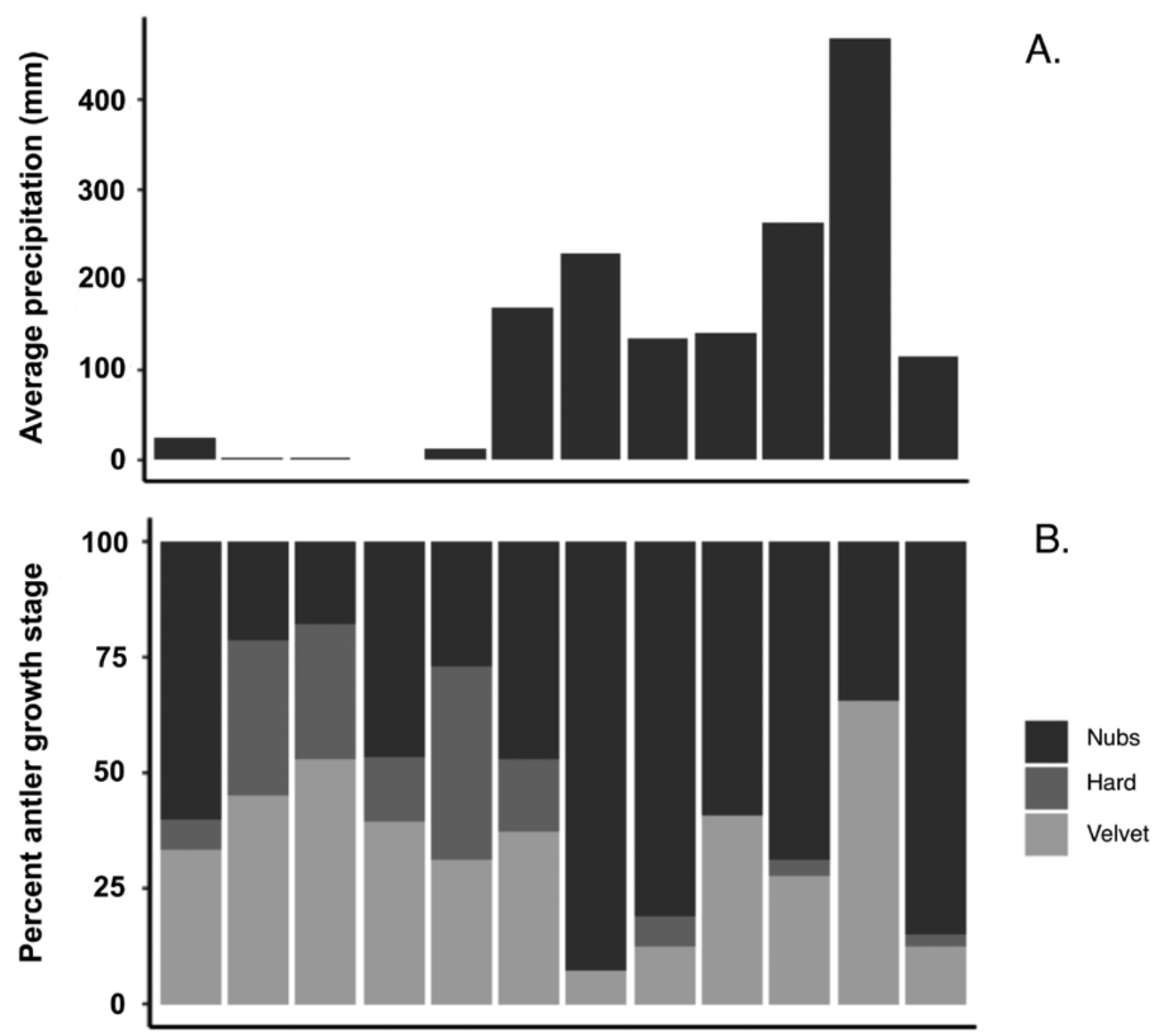

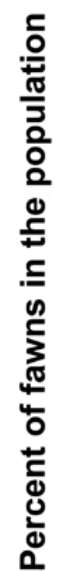

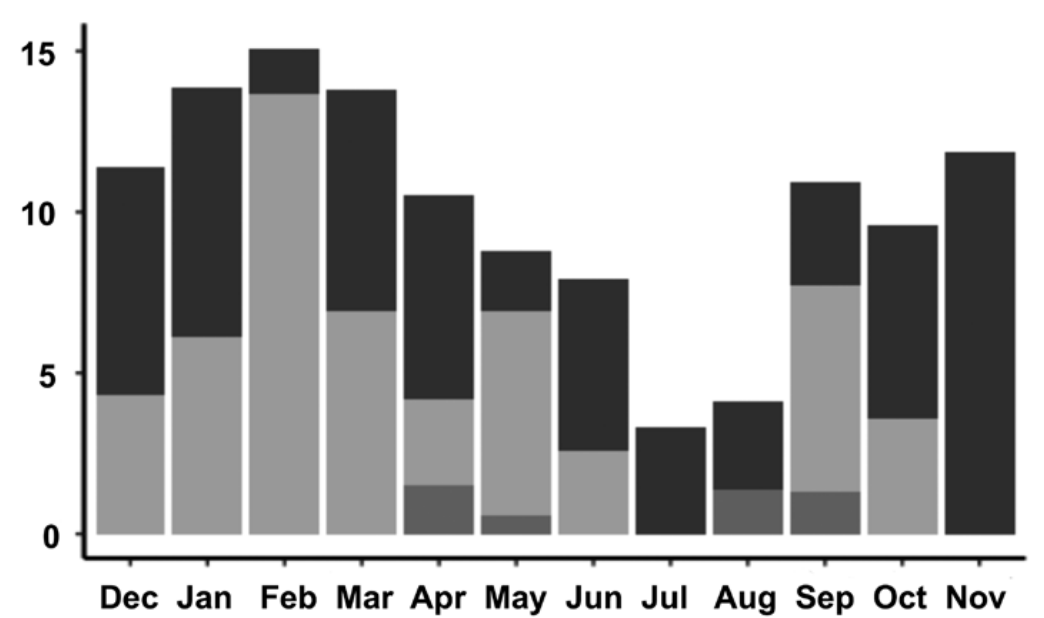

C.

A.

Fig. 1.-A) Average monthly precipitation (mm) during 2011-2017 in Santa Rosa National Park, northwestern Costa Rica. B) Proportion of adult male deer (Odocoileus virginianus) with antlers in different stages of antler growth as determined from camera-trapping photographs $(n=461$, monthly mean $=38$, monthly range $=14-119)$ collected during 2011-2017 in Santa Rosa National Park in northwestern Costa Rica. C) Proportion of fawns in monthly samples of all aged deer as determined from camera-trapping photographs $(n=1,336$, monthly mean $=111$, monthly range $=38-336$ ) collected during 2011-2017 in Santa Rosa National Park in northwestern Costa Rica. 
of the rivers and streams in the study area run dry and the remaining waterholes become important providers of free water for wildlife (Campos and Fedigan 2009).

Photograph collection.-During the dry and wet seasons of 2011-2017, automatic trail cameras (Bushnell, Trophy Cam models 119436, 119446, 119456; Bushnell Corp., Overland Park, Kansas) were deployed at 101 different sites within SRNP. Cameras were place at waterholes $(n=25)$, on pathways (e.g., roads, human trails, and animal paths; $n=47$ ) that jaguars (Panthera onca) were likely to use, and at random sites within the forest $(n=29)$ for 34-365 days during a year. The duration of continuous camera deployment each year was affected by camera malfunctions, limited battery life in combination with logistics of camera checks, and initial study design for deployment. Each camera was attached to a tree at a height of approximately $40 \mathrm{~cm}$ and set to be active for $24 \mathrm{~h} /$ day. Cameras were set either in video mode (30-s video, minimum $1 \mathrm{~s}$ between successive videos) or photograph mode (three consecutive photos with a minimum delay of $1 \mathrm{~s}$ between consecutive triggers). Once deployed, cameras were checked every month or so to replace batteries and change SD memory cards, if necessary. This research followed ASM guidelines (Sikes et al. 2016).

Photographs or videos were considered an independent photo events of a species if they were: 1) taken at least 30 min apart (e.g., a series of three photos of the same animal[s] taken in consecutive seconds $=1$ photo event); 2) consecutive photos of the same species could be identified as different individuals (spots, scars, horns or antlers, sex) and not part of the same group (e.g., $>15$ min apart, going in opposite directions $=$ two photo events); or 3) photos of the same species separated by photos of a different species (e.g., species 1, followed 2 min later by a species 2 , followed 5 min later by species $1=$ one species with two photo events and another species with one photo event).

Photograph classification.-Using the videos or multiple photos we obtained, we used physical characteristics and size comparisons to segregate white-tailed deer by sex and age (cf. Dasmann and Taber 1956:80). An individual was considered an adult (non-fawn) male if male genitalia (testes) could be observed or if there was any indication of antlers. Antlers were categorized as "nubs" (pedicels covered in velvet), "velvet" (growing antlers covered in velvet with rounded tine ends), or "hard" (velvet-less, fully formed antlers; rarely, hard antlers with shedding velvet). A deer was classified as an adult (non-fawn) female if antlers or testes were not observable (but should have been), or if they were accompanied by a fawn and no male characters could be discerned. Most fawns were identified by a spotted coat; those whose shoulder height only reached the bottom to lower third of a doe's belly were considered "small" (probably 2 weeks to 2 months old) and all others were considered "large" (3-4 months old). Non-spotted fawns were identified by their small body size compared to adults (if an adult was present), and a relatively high-crowned, short, blunt-muzzled head with long ears in proportion to head size. An individual was categorized as an unknown adult if it had an adult body shape or size, but the head was off camera or hidden. A deer was un-categorized if only a portion of the deer was visible, such as a tail or leg. Three of us (AMS, TKF, and
VHM) identified all photos; we trained together and repeatedly interacted on questionable categorizations to minimize misclassifications (Newbolt and Ditchkoff 2019).

Data interpretation and assumptions.-For the purposes of identifying the reproductive seasonality of deer, we made the following assumptions concerning deer morphology and development based on North American observations. Gestation ranges from 187 to 222 days (6-7 months-Smith 1991). Mothers spend most of their time away from their newborn fawns, but fawns gradually spend more time in association with her ( $\sim 50 \%$ at 3 months; $\geq 60-70 \%$ at 4 months-Schwede et al. 1994). Small spotted fawns were 2 weeks to 2 months old, and large spotted fawns were 3 or 4 months old; spots of fawns normally are not visible after 4 months of age (Ditchkoff 2011). Loss or casting of antlers signals the end of the fertile season, some males that recently shed antlers might not be classified as males because the pedicle "bump" would be hard to observe for the first 1-2 months, antler regrowth takes 5-6 months (i.e., the period antlers are in velvet), velvet is removed by rubbing in as little as $24 \mathrm{~h}$, hard antlers remain for 3-5 months (Hirth 1977; Goss 1983; Sauer 1984; Demarais and Strickland 2011).

Over the course of the 7 study years (2011-2017), no cameras were operating during 34 months (40\% of months) and for $0-10$ months (mean $=4.9$ months) in any one year (Supplementary Data SD2), and because the number of cameras varied among years, as well, we obtained no photos of adult male deer during 38 months and no photos of fawns in 53 months. In addition, the shortest intervals to which we could ascribe parturition or breeding dates were more than a month (and likely several months). Therefore, meager data and the imprecision in which we could estimate either parturition or breeding dates precluded any assessment of the amount or potential causes of variation among years in the timing of in deer reproduction. Concomitantly, we restricted our statistical analyses to simple contingency table analyses, using Pearson's chisquare test for independence to confirm significant differences among all months, and then, with testing of adjusted Pearson residual values along with visual inspection, assessed variation among months (and thus consecutive months to relate them to wet and dry seasons). We believe that this is all the interpretation that the data will support and more sophisticated analyses are neither warranted or needed.

\section{Results}

Of 1,362 individual deer identified in photos and videos, 1,336 (98\%) were classified as to age or sex. This total included 139 fawns, 582 adult females, 461 adult males, and 154 adults of unknown sex.

Adult male deer with antlers in velvet were observed in all months but June, August, and November, and most often during January-May (Fig. 1B; $X_{11}^{2}=80.36, P<0.0001$ ). Residual values indicated that the proportion of males in velvet was statistically higher than average in January and April, and lower during August through November. Males with hard antlers were observed in every month, with most occurring during June-October $\left(X^{2}{ }_{11}=89.95, P<0.0001\right)$. Residual values indicated that the 
proportion of males with hard antlers was statistically higher than average in June, July, September, and October, and lower during January, February, and April. At least $34 \%$ of all male deer in any given month (and as many as 93\%) had growing or hard antlers.

Small spotted fawns (i.e., those presumably 2 weeks to 2 months old) were seen during December to June with a substantial peak in February (14\% of total deer), and again during September and October (i.e., in 9 of 12 months; Fig. $\left.1 \mathrm{C} ; X_{11}^{2}=31.30, P<0.001\right)$. Residual values indicated that the proportion of small spotted fawns was statistically higher than average in February and May, and lower during April and November. Large spotted fawns, when they could be discerned, were documented in April and May, and again in August and September. Older, nonspotted fawns were observed year-round. The proportion of twin fawns (versus single fawns) seen in independent photos did not differ $\left(X^{2}=0.91, P=0.34\right)$ between dry and wet seasons ( $7 \%$ of 44 versus $0 \%$ of 13 , respectively).

\section{Discussion}

In northwest Costa Rica, both antler and fawn observations were consistent in identifying the timing of births of whitetailed deer. Observations of antler type and presence suggest year-round breeding, with most breeding occurring during the wet season. Observations of fawns suggested year-round parturition, with the majority of births occurring during the dry season, but a second peak towards the latter part of the wet season. The results also are similar to the reports from the same region (Rodríguez and Solís 1987, 1994; Solís et al. 1987), though because of our larger samples, we determined that breeding and parturition likely occurred over longer periods of time and even in a different season.

Nutritional needs of reproducing females and growing fawns vary with their state of reproduction and age, respectively (Hewitt 2011). Gestation accounts for about $20 \%$ of the energy needed to raise fawns, whereas lactation accounts for $80 \%$. Fawns are weaned at 3 months of age and maximum energy requirements peak when they are 4-6 months old. Thus, in seasonal environments where food supplies vary throughout the year, there is often a necessity for deer to give birth at an appropriate time of year for optimal survival and growth of offspring (Loudon and Brinklow 1992; Asher 2011). In the dry forest in northwest Costa Rica, plant food resources vary seasonally with rainfall patterns, and seasonal activity of a variety of animal species reflects these changes (e.g., Rockwood 1975; Janzen 1993; Orkin et al. 2019). A high percentage of the tree species lose their leaves during the long dry season, and tree species produce new leaves both in December to January and especially at the onset of the first rains during late April-June (Castro et al. 2018). Most species flush large leaves and continue leaf production into July, and a few species stay in full leaf in both seasons (Frankie et al. 1974), as do about one-half of the treelet and shrub species (Opler et al. 1980). There is a large peak in the number of fruiting tree species and fruit biomass during January-May (Williams 1984), but fruit production continues throughout the year (Frankie et al. 1974; Orkin et al. 2019).
Most white-tailed deer in northwestern Costa Rica may maximize reproductive output by gaining nutritional condition during the wet season, and having fawns during the beginning of the dry season when some new leaf production occurs. During the dry season, abundant fruit is on the ground and likely some is consumed by deer (Janzen 1983; Herrera 1989; Mandujano and Martinez-Romero 1997), and year-round evergreen vegetation is available; thus, deer may be able to lactate sufficiently through weaning. Weaned fawns may take advantage at the beginning of the wet season to maximize growth. Still, females giving birth throughout the year may have habitat-use behaviors that allow them and their fawns to be successful, as well, thus continuing the habit of reproducing throughout the year. We did not discover any season-related fawn vulnerability to predation or to weather-related stress, nor how these factors interact with food availability.

In sum, the lack of seasonal variation in photoperiod allows deer to breed year-round (primary driver), but the seasonal occurrence of rainfall and thus food availability (secondary driver) produces notable variation during the year. Some seasonality of reproduction of mammals in tropical environments where photoperiod does not provide a seasonal key is not unusual (Bronson 2009; Hufenus et al. 2018). Reproductive patterns of tropical cervids may have evolved in response to seasonal fluctuations in availability of specific food items, local resource competition among sympatric species, or predation patterns, and these may be directly related to rainfall patterns (Asher 2011). Thus, white-tailed deer in the tropics are likely a species that has retained the "endogenous rhythmicity" evolved by their temperate ancestors (Loudon and Brinklow 1992). As environmental seasonality varies across tropical landscapes, it seems probable that reproduction by white-tailed deer would vary, as well, even over relatively short distances (Richter and Labisky 1985). Thus, previous reports of deer reproduction in the tropics, as varied as they might be (parturition year-round versus in the dry season versus wet season), could each be telling a different true story, regardless of the robustness of the data (Bronson 2009), and thus could reflect how flexible reproduction by white-tailed deer might be.

\section{ACKNOWLeDgments}

We thank the National University of Costa Rica, the Rufford Foundation, the Gifford-Wyle family, and the National Ministry of Science and Technology of Costa Rica for financial support, as well as all of the volunteers and students who collaborated in the field work. We also thank R. Blanco and the personnel of Guanacaste Conservation Area for their support in the field, M. Timm and S. Maji for help with photo identification, and S. DeStefano and two anonymous reviewers for reading the manuscript and providing helpful suggestions for improvement.

\section{SupPlementary DATA}

Supplementary data are available at Journal of Mammalogy online. 
Supplementary Data SD1.-Monthly precipitation (mm) in Liberia, northwestern Costa Rica.

Supplementary Data SD2.-Numbers of photos used in analysis of seasonal reproduction of white-tailed deer in northwestern Costa Rica.

\section{Literature Cited}

Asher, G. W. 2011. Reproductive cycles of deer. Animal Reproduction Science 124:170-175.

BLOUCH, R. A. 1987. Reproductive seasonality of the white-tailed deer on the Colombian Llanos. Pp. 339-343 in Biology and management of the Cervidae (C. M. Wemmer, ed.). Smithsonian Institution Press, Washington, D.C.

BozA, M. 1992. National parks of Costa Rica. Northwestern University Press, Evanston, Illinois.

Branan, W. V., AND R. L. Marchinton. 1987. Reproductive ecology of white-tailed deer and red brocket in Suriname. Pp. 344-351 in Biology and management of the Cervidae (C. M. Wemmer, ed.). Smithsonian Institution Press, Washington, D.C.

Brokx, P. A. 1984. South America. Pp. 525-546 in White-tailed deer ecology and management (L. K. Halls, ed.). Stackpole Books, Harrisburg, Pennsylvania.

Bronson, F. H. 2009. Climate change and seasonal reproduction in mammals. Philosophical Transactions of the Royal Society of London, B. Biological Sciences 364:3331-3340.

Campos, F. A., And L. M. Fedigan. 2009. Behavioral adaptations to heat stress and water scarcity in white-faced capuchins (Cebus capucinus) in Santa Rosa National Park, Costa Rica. American Journal of Physical Anthropology 138:101-111.

Castro, S. M., G. A. Sanchez-Azofeifa, and H. Sato. 2018. Effect of drought on productivity in a Costa Rican tropical dry forest. Environmental Research Letters 13:045001.

Dasmann, R. F., and R. D. Taber. 1956. Determining structure in Columbian black-tailed deer populations. Journal of Wildlife Management 20:78-83.

Demarais, S., and B. K. Strickland. 2011. Antlers. Pp. 107-145 in Biology and management of white-tailed deer (D. G. Hewitt, ed.). CRC Press/Taylor and Francis Group, Boca Raton, Florida.

Ditchкoff, S. S. 2011. Anatomy and physiology. Pp. 43-73 in Biology and management of white-tailed deer (D. G. Hewitt, ed.). CRC Press/Taylor \& Francis Group, Boca Raton, Florida.

Frankie, G. W., H. G. Baker, And P. A. Opler. 1974. Comparative phenological studies of trees in tropical wet and dry forests in the lowlands of Costa Rica. Journal of Ecology 62:881-919.

Gallina, S., S. Mandujano, J. Bello, H. Lopez-Fernandez, AND M. WeBER. 2010. White-tailed deer Odocoileus virginianus (Zimmermann, 1780). Pp. 101-118 in Neotropical cervidology: biology and medicine of Latin American deer (M. Barbanti and S. González, eds.). Funep, Jaboticabal, Brazil, and IUCN, Gland, Switzerland.

Gallina, S., AND H. Lopez Arevalo. 2016. Odocoileus virginianus. The IUCN Red List of Threatened Species 2016:e. T42394A22162580.

Goss, R. J. 1983. Deer antlers - regeneration, function, and evolution. Academic Press, New York.

Herrera, C. M. 1989. Vertebrate frugivores and their interaction with invertebrate fruit predators: supporting evidence from a Costa Rican dry forest. Oikos 54:185-188.

HewitT, D. G. 2011. Nutrition. Pp. 75-105 in Biology and management of white-tailed deer (D. G. Hewitt, ed.). CRC Press/Taylor and Francis Group, Boca Raton, Florida.
HiRTH, D. 1977. Observations of loss of antler velvet in white-tailed deer. The Southwestern Naturalist 22:278-280.

Hufenus, R., ET AL. 2018. Seasonality of reproduction in Asian elephants Elaphas maximus and African elephants Loxodonta africana: underlying photoperiodic cueing? Mammal Review 48:229-332.

JANZEN, D. H. 1983. Costa Rican Natural History. University of Chicago Press, Chicago, Illinois.

JAnZEN, D. H. 1993. Caterpillar seasonality in a Costa Rican dry forest. Pp. 448-477 in Caterpillars - ecology and evolutionary constraints on foraging (N. E. Stamp and T. M. Casey, eds.). Chapman and Hall, New York.

JANZEN, D. H. 2011. Costa Rica's Área de Conservación Guanacaste: a long march to survival through non-damaging biodevelopment. Biodiversity 1:7-20.

JANZEN, D. H., AND W. HALlWACHS. 2016. Biodiversity conservation history and future in Costa Rica: the case of Área de Conservación Guanacaste (ACG). Pp. 290-341 in Costa Rican ecosystems (M. Kappelle, ed.). University of Chicago Press, Chicago, Illinois.

Jimenez M., Q., E. Carrillo J., And M. Kappelle. 2016. The northern Pacific lowland seasonal dry forests of Guanacaste and the Nicoya Peninsula. Pp. 247-289 in Costa Rican ecosystems (M. Kappelle, ed.). University of Chicago Press, Chicago, Illinois.

Kalacska, M., G. A. Sanchez-AzofeifaA, J. C. Calvo-Alvarado, M. Quesada, B. Rivard, And D. H. Janzen. 2004. Species composition, similarity and diversity in three successional stages of a seasonally dry tropical forest. Forest Ecology and Management 200:227-247.

KLEIN, E. H. 1982. Phenology of breeding and antler growth in white-tailed deer in Honduras. Journal of Wildlife Management 46:826-829.

Lincoln, G. A. 1992. Biology of seasonal breeding in deer. Pp. 565574 in The biology of deer (R. D. Brown, ed.). Springer Verlag, New York.

Lincoln, G. A., AND R. V. ShorT. 1980. Seasonal breeding: nature's contraceptive. Recent Progress in Hormone Research 36:1-52.

Loudon, A. S. I., AND B. R. BRINKLOW. 1992. Reproduction in deer: adaptations for life in a seasonal environment. Pp. 261-278 in The biology of deer (R. D. Brown, ed.). Springer Verlag, New York.

Mandujano, S., and L. E. Martinez-Romero. 1997. Fruit fall caused by chachalacas (Ortalis poliocephala) on red mombin trees (Spondias purpurea): impact on terrestrial fruit consumers, especially the white-tailed deer (Odocoileus virginianus). Studies on Neotropical Fauna and Environment 32:1-3.

Newbolt, C. H., and S. S. Ditchкoff. 2019. Misidentification error associated with classifications of white-tailed deer images. Wildlife Society Bulletin 43:527-536.

Opler, P. A., G. W. Frankie, AND H. G. Baker. 1980. Comparative phenological studies of treelet and shrub species in tropical wet and dry forests in the lowlands of Costa Rica. Journal of Ecology 68:167-188.

Orkin, J. D., F. A. Campos, M. S. Myers, S. E. Cheves Hernandez, A. Guadamuz, and A. D. Melin. 2019. Seasonality of the gut microbiota of free-ranging white-faced capuchins in a tropical dry forest. The ISME Journal 13:183-196.

Powers, J. S., J. M. Becknell, J. Irving, and D. Pèrez-Aviles. 2009. Diversity and structure of regenerating tropical dry forests in Costa Rica: geographic patterns and environmental drivers. Forest Ecology and Management 258:959-970.

Richter, A. R., AND R. F. LAbisky. 1985. Reproductive dynamics among disjunct white-tailed deer herds in Florida. Journal of Wildlife Management 49:964-971. 
Rockwood, L. L. 1975. The effects of seasonality on foraging in two species of leaf-cutting ants (Atta) in Guanacaste Province, Costa Rica. Biotropica 7:176-193.

Rodríguez, M., AND V. Solís. 1987. Ciclo reproductive del venado cola blanca en la Isla San Lucas, Costa Rica. Pp. 31-32 in Actas del primer taller nacional sobre el venado cola blanca (Odocoileus virginianus) del Pacifico seco (V. Solis, M. Rodriguez, and C. Vaughan, eds.). Universidad Nacional, Heredia, Costa Rica.

Rodríguez, M. A., AND V. Solís. 1994. Ciclo de vida del venado cola blanca en la Isla San Lucas, Costa Rica. Pp. 63-71 in Ecología y manejo del venado cola blanca en México y Costa Rica (C. Vaughan and M. S. Rodríguez, eds.). Editorial de la Universidad Nacional, Heredia, Costa Rica.

Sauer, P. R. 1984. Physical characteristics. Pp. 73-90 in White-tailed deer ecology and management (L. K. Halls, ed.). Stackpole Books, Harrisburg, Pennsylvania.

Saunders, G. B., A. D. Holloway, and C. O. Handley. 1950. A fish and wildlife survey of Guatemala. U.S. Dep. Inter. Special Sci. Rep., Wildlife, No. 5. Washington, D.C.

Schwede, G., H. Hendrichs, AND C. Wemmer. 1994. Early motheryoung relations in white-tailed deer. Journal of Mammalogy 75:438-445.

Sikes, R. S., and The Animal Care and Use Committee of the American Society of Mammalogists. 2016. 2016 Guidelines of the American Society of Mammalogists for the use of wild mammals in research and education. Journal of Mammalogy 97:663-688.
Sмiтн, W. P. 1991. Odocoileus virginianus. Mammalian Species 388:1-13.

Solís, V., M. Rodríguez, and C. Vaughan. 1987. Actas del primer taller nacional sobre el venado cola blanca (Odocoileus virginianus) del Pacifico Seco, Costa Rica. Universidad Nacional, Heredia, Costa Rica.

Stuwe, M. 1985. Aspects of structure and reproduction of whitetailed deer populations, Odocoileus virginianus, in Venezuela and Virginia. Saugetierkundeliche Mitteilungen 32:137-141.

Verme, L. J., AND D. E. Ullrey. 1984. Physiology and nutrition. Pp. 91-118 in White-tailed deer ecology and management (L. K. Halls, ed.). Stackpole Books, Harrisburg, Pennsylvania.

Wainwright, M. 2007. The mammals of Costa Rica. Cornell University Press, Ithaca, New York.

Waylen, P. R., C. N. Caviedes, and M. E. Quesada. 1996. Interannual variability of monthly precipitation in Costa Rica. Journal of Climate 9:2606-2613.

Webb, J., AND D. Nellis. 1981. Reproductive cycle of whitetailed deer of St. Croix, Virgin Islands, USA. Journal of Wildlife Management 45:253-258.

Williams, K. D. 1984. The Central American tapir (Tapirus bairdii Gill) in northwestern Costa Rica. Ph.D. dissertation, Michigan State University, East Lansing.

Submitted 13 November 2018. Accepted 18 October 2019. Associate Editor was Rafael Reyna. 